Јелена Н. Тодоровић

УДК 371.3:821.163.41

Универзитет у Београду

Стручни рад

10.19090/mv.2016.7.199-215

Филолошки факултет - докторске студије, модул Српска књижевност

Београд

jelena_4@yahoo.com

\title{
ЖАНРОВСКИ ЕЛЕМЕНТИ ОБРАЗОВНОГ РОМАНА КАО МОГУЋИ ИНТЕРПРЕТАТИВНИ СТОЖЕР У ТУМАЧЕЊУ ЖИВОТА И ПРИКЉУЧЕНИЈА ДОСИТЕЈА ОБРАДОВИЋА (МЕТОДИЧКА ПЕРСПЕКТИВА)
}

\begin{abstract}
АПСТРАКТ
У раду се разматрају могућности наставног тумачења Живота u прикљученија Доситеја Обрадовића помоћу елемената образовног романа. Први дио рада посвећен је теоријској проблематици те претпоставке - како аутобиографију посматрати на основу жанровских одредница неког другог жанра, које су условности таквог поступања, а која добит за потенцијалну интерпретацију. Методичка перспектива се уводи у другом дијелу рада. Ту се разматра начелна проблематика жанровског приступа дјелу у настави, али нагласак је на жанровској структури образовног романа која прожима Доситејево дјело. Закључак је да та структура може да представља средишњу тачку, односно кључни интеграциони чинилац интерпретације из којег се онда могу изводити сви остали, и то су нарочито значајни они аспекти те структуре који су у служби образовања читалаца.
\end{abstract}

Кључне ријечи: образовни роман, аутобиографија, читалац, жанр, наставна интерпретација

GENRE-BASED ELEMENTS OF THE EDUCATIONAL NOVEL AS A POSSIBLE INTERPRETATIVE BASE IN INTERPRETING ŽIVOT I PRIKLJUČENIJA BY DOSITEJ OBRADOVIĆ (METHODOLOGICAL PERSPECTIVE)

ABSTRACT 
The paper deals with a different way of interpreting Život $i$ priključenija by Dositej Obradović using the elements of the educational novel. The first part of the paper is devoted to the theoretical issues of that assumption - how to observe an autobiography as something based on generic determinants of another genre; what are the requirements of such practice and what are the benefits for the interpretation. Methodological perspective is introduced in the second part of the paper. It discusses the principal issues of genre-based approach in the classroom, but the emphasis is on the genre-based structure of the educational novel that permeates Dositej's work. The conclusion is that the structure can represent the central point, in other words the key integrational factor of interpretation, from which all other factors can be drawn. Aspects and structures that serve as an educational model for readers are of particular importance.

Key words: educational novel, autobiography, reader, genre, teaching interpretation

\section{1. УВОД}

Више од два вијека је прошло од када су се појавила прва дјела Доситеја Обрадовића. Значај овог писца и просвјетитеља у српској књижевности и култури потврђен је до сада небројено пута. Чак и када je његово дјеловање било предмет критике, нису изостајали бројни афирмативни ставови. Једна од неспорних чињеница је да је Доситеј у српској књижевности својим дјелом увео нови образац комуникације писца и читаоца. Он се огледа у новој улози језика, поетској грађи која се користи у просвјећивању, непосредношћу излагања, присуством усмености, анегдотским конкретизовањем времена и простора. Преовлађујући просвјетитељски дискурс је, такође, прожет елементима сентиментализма који му дају посебан тон (Марковић 2008: 18). Доситеј често умјесто „давања готових судова и максима у исказивању поуке, [писац] користи пословице и афористичке исказе, водећи рачуна и о нијансама значења и помаже се и емоционалном обојеношћу исказа“" (Милинчевић 2008: 28). Као што је већ истакнуто, врло је честа и анегодота код Доситеја, а „,анегдота је уносила говорни стил у писани дискурс, а озбиљно излагање често водила у привлачно и заводљиво поље козерије и комике“ (Иванић 2008: 222). Стога, иако је његово цјелокупно дјело обиљежено васпитном интенцијом, треба имати у виду и ,лакоћу његовог језика и стила“ и често смјењивање стилског кода (Кречмер 2008: 77). 
Једно од питања које се само намеће јесте и како свим овим многобројним, често диспаратним, особеностима Доситејевог дјела, на која се пажња скреће у савременим поручавањима овог писца - изузетном стилу, комици, анегдотском и козерском, посредованом, али постојаном дидактизму, сентименталним пасажима, жанровској поливалентности и синкретичности, приступити у настави. Наравно, у овом, као и у низу других случајева, савремена методика нуди средства и упућује на начине помоћу којих се може остварити инвентивна и сврсисходна интерпретација. И поред тога, Доситејево дјело је и даље рјечит примјер за тешкоће наставног тумачења. Својом структуром, једнако као и специфичним положајем не само у историји књижевности, него и шире, у културној историји, представља добар мамац за потенцијални методолошки редукционизам. Са друге стране, постоји опасност и од плурализама који, узимајући у обзир све особине пишчевог дјела, може лако остати без тачке или тачака у којима би се сусретале идеје интерпретације. Дакле, у случају редукционизма дјело би остало само примјер књижевноисторијских чињеница, а у случају неконцентрисаног плурализма, примјер за уочавање и анализирање вишеслојних стилских и идејних регистара. Чини се да је опасност од таквог поступања понајвиша у случају Доситејеве аутобиографије, а ваља узети у обзир да је ријеч о дјелу које овог писца понајвише репрезентује у школским програмима.

Да би се све претпостављене потешкоће предуприједиле и на најбољи могући начин афирмисали елементи који ће позитивно условљавати наставну интерпретацију, треба пронаћи оне чиниоце који ће све њене аспекте обједињавати. Наравно, могуће је пронаћи низ чинилаца и при томе се ослонити на поуздане препоруке које долазе од савремене методике. У овом случају у циљу проналажења прихватљивог рјешења, разматраће се елементи образовног романа, као жанровске структуре која прожима Доситејево дјело на врло специфичан начин. Како би се уопште разматрала таква могућност, ваља се најприје, бар укратко, осврнути на опсег појма образовни роман и његову улогу у науци о књижевности, као и на претпоставке разумијевања аутобиографије, начелно нефикционалног жанра, као умногоме еквивалентног фикционалном жанру образовног романа. Овој проблематици ће бити посвећен први дио рада. У другом дијелу ће се разматрати претпоставке наставног тумачења Доситејевог дјела помоћу истакнуте жанровске структуре. 


\section{2. АУТОБИОГРАФИЈА И(ЛИ) ОБРАЗОВНИ РОМАН}

Иза појма Bildung, који се у литератури најчешће не преводи, крију се сљедећи садржаји: образовање, едификација, обучавање, формирање, култивација, просвјећивање, усавршавање, односно процес, али истоврмено и крајњи резултат образовања, или пак оличење културних вриједности на којима појединац, друштвени слој или народ заснивају своје духовно постојање (видјети: Dobrijević 2006: 119-120; Jakobs, Krauze 2000: 381). Иако нас овдје занима искључиво у оквиру литерарног дискурса, као Bildungsroman, важно је имати на уму комплексност овог појма, који далеко превазилази и све напријед побројано. Његова сложеност условила је и бројне расправе о томе како уопште треба разумјети образовни роман, како га позиционирати у историји књижевности и како сагледати његов значај за традицију романа у западној култури. Након површног прегледа неколико текстова на ову тему, јасно је да су се закључци изводили у најразличитијим могућим смјеровима.

Ипак, разлози бављења овим жанром (и наджанровским аспектима које имплицира), крију се у његовом методолошком потенцијалу, који је постојан упркос свим потешкоћама које се јављају усљед бурне историје појма, али и усљед инхерентних ограничења која са собом носи сваки приступ тексту помоћу жанровских одредница. Иначе, без обзира на начелни став о улози жанра и историјској перспективи у проучавању књижевности, јасно је да су појмови „жанра и епохе неопходни науци о књижевности: само тим инструментима она може рашчланити и средити свој огромни историјски материјал“ (Jakobs, Krauze 2000: 379). Међутим, као што и аутори на овом мјесту примјећују, приступ помоћу жанра увијек мора имати оправдање у самом тексту. Осим тога, важно је одабрати довољно флексибилну, али не и баналну, дефиницију жанра која ће омогућити и флексибилнији приступ. Како се овдје ради о наставном тумачењу, ваља посебно обратити пажњу на те околности, о чему ће касније бити више ријечи.

Иако сваки приступ тексту помоћу жанровских одредница, ма колико разложан био, у одређеном тренутку постаје проблематичан, треба истаћи да је ситуација у случају образовног романа нарочито комплексна, јер је овај жанр индикатор озбиљних промјена у култури (и у тренутку када се појавио, а и касније када се модификовао). Тако се појава образовног романа на крају 18. вијека поклапа са покушајима да се формулише теоријски концепт образовања и развије ново поимање појединца и његовог односа према друштву. Ова поклапања се, заправо, морају схватити као фактори његовог настанка: 
„Питање који фактори одређују развој појединца, како он свом постојању може дати општеважећу, узорну оријентацију и 'смисао', које захтеве сме да постави а које захтеве друштва да прихвати као дужност, сва та питања о путу и циљу индивидуалних животних путева постављена су са посебним интензитетом у социјално и духовноисторијски преломној ситуацији на крају доба просветитељства. Други фактор при настајању образовног романа јесте надирање јасне свести о непоновљивости појединачног човека.“ (Jakobs, Krauze 2000: 382)

Аутори истичу како се на крају образовног процеса догађа помирење индивидуе и свијета, тако што се индивидуална хтјења уклапају у општа.

Појава образовног романа крајем 18. вијека тиче се и још шире проблематике - у њему се проналази начин да се искаже дух новог стања, и то управо помоћу тематизовања животног пута младог човјека, односно младости. Младост је, дакле, један од одређујућих елемената овог романа, и то на начин да дубоко задире у изграђивање једне нове културне оријентације:

„Почетком XVIII века требало је урадити и нешто много значајније него што је ново промишљање младости. Готово не примећујући, у сновима и ноћним морама такозване 'двоструке револуције' Европа урања у модерност, али при том не поседује и културу модерности. Ако младост, стога, осваја симболичко централно место, па се јављају 'велике приче' Bildungsromana, то је зато што Европа мора да прида смисао не толико младости, колико модерности.“ (Moreti 2000: 419)

Специфичност младости се, додаје Морети, огледа у покретљивости и унутрашњим немирима који су истовремено суштинска обиљежја модерности. Из свега се да̂ закључити да је ријеч о књижевном облику који далеко надилази уобичајене жанровске одреднице и у себе асимилује симболичке структуре које оличавају промјену цјелокупне културне парадигме.

Када се за тренутак вратимо нешто уже схваћеном проблему жанра, морамо запазити да образовни роман црпи много из традиције различитих облика, на примјер, из пикарског авантуристичког романа, а нарочито из аутобиографије. На тај начин долазимо и до проблематике приступа Доситејевом дјелу помоћу жанровских одредница. Јасно је да се Живот и прикљученија непроблематично може означити искључиво као аутобиографија. Али, примјећено је и да Доситејево дјело игнорише класицистичку тежњу ка строгом разграничавању жанрова и представља жанровски изузетно синкретично дјело, те да понајвише црпи из средњовјековних 
хагиографија, али и да средишње мјесто у тако жанровски синкретичном дјелу заузима начело личности, новооткривеног човјека-појединца (Стојнић 1989: 174 и даље).

Већ овдје смо на трагу потенцијалних веза између Доситејеве аутобиографије и жанровских карактеристика образовног романа. О Доситејевој аутобиографији се увијек говори као о нарочитом остварењу у оквиру тога жанра, и то из више разлога. Прво, као што је већ и поменуто, успијева да на специфичан начин искористи матрицу средњовјековне хагиографије и модификује је у духу доба у којем је настала, јер „дух просвећености [je] формирао аутобиографију као књижевност која препознаје буђење субјекта, његов излазак у разумевање света као нов облик само-разумевања“ (Ломпар 2000: 431). Друго, и овдје можда још значајније, она се одликује завршеношћу, цјеловитошћу са којом већ по својој природи аутобиографија води борбу, јер наспрам себе има отвореност живота. Али, јунак ове аутобиографије доживљава преобраћење. Преобраћење које се догађа у процесу образовања главног јунака је сасвим посебно, без обзира што црпи из богате (средњовјековне) (ауто)биографске традиције, јер је „сада - под владом просвећено-модерног духа, под владом, дакле, зрелости и слободе ума - преобраћање које утемељује човека у свет и чини га савременим“ (Исто: 432). Доситејев јунак је просвијећено биће, а не само биће просвијећености, што аутобиографији у крајњем исходу омогућава завршеност, иако се то противи њеном жанровском устројству (Исто: 433).

Пишући о Дилтајевим запажањима о томе да је цјелина одлучујућа категорија за Гетеовог Вилхелма Мајстера, Морети истиче сљедеће:

„Овде је незамислива ситуација да социјализација може да изазове кризу или да индивидуално формирање примора на жртву. Развој личности и интеграција су комплементарне и конвергентне путање, и на тачки њиховог сусрета и равнотеже налази се пуна и двострука епифанија смисла, односно 'зрелост'. Када се то достигне, нарација је испунила свој циљ и може мирно да се заврши.“ (Moreti 2000: 428)

Имајући ово у виду, јасно је да се између Доситејеве аутобиографије и класичног образовног романа успостављају врло очигледне везе које се тичу саме суштине њихове унутрашње структуре. ${ }^{1}$

1 Иако није успостављена потпуна жанровска еквиваленција и увијек се само условно може говорити о структури образовног романа у тексту овог Доситејевог дјела, чињеница је да је дух епохе, који се најбоље одразио у образовном роману, свепрожимајући и у Доситејевом дјелу, и то на истовјетан начин као и у образовном роману. Осим тога, ако прихватимо условност 
Наравно, при инсистирању на постојећим везама, мора се водити рачуна о свим условностима. Оне су присутне у свим аспектима наше проблематике. Ако се претпостави да је образовни роман настао директно од аутобиографије, црпећи уз то средства и из других жанрова, треба водити рачуна о томе да се за разлику од аутобиографије која остаје у оквирима реалног искуства, у образовном роману налазе и елементи утопијског, уз природно појачану литераризацију, односно фикционализацију аутобиографског жанра (видјети: Bajazetov-Vučen 2000: 511 и даље). Са друге стране, већ сада се то може истаћи, Доситејева аутобиографија није ускраћена за елементе утопијског, нити јој недостаје снажна литераризација, односно фикционализација. Стога, она се сасвим приближила и по смислу и по форми образовном роману. Када се догоди овакво поклапање, како се то догодило код Доситеја, прецизно разликовање жанровских одредница једног или другог жанра је врло тешко:

„И аутобиографија слика животни пут појединца и схвата га као кохерентан и смисаон процес. Сродство ове две књижевне врсте потврђује се у јакој аутобиографској обојености многих образовних романа [...]. Блискост аутобиографије и образовног романа види се и у томе што оба жанра одражавају смену епоха у последњој трећини XVIII века. За историју жанра аутобиографије то значи да старије форме аутопортретисања (религијску исповест, пословну аутобиографију и авантуристичку животну причу) потискује нови тип [...]. Доказано је да се аутобиографија и по средствима приказивања у све већој мери приближава роману [...]. А када се аутобиографија и (образовни) роман толико приближе у тематици и начину приказивања, намеће се и закључак да се они уопште и не могу јасно раздвојити.“ (Jakobs, Krauze 2000: 382-383)

Овоме у прилог иде и то што се аутор у типичном образовном роману, какав је Гетеов, не може разликовати од приповједача, јер су сасвим изједначени (видјети: Bajazetov-Vučen 2000: 516), једнако као и у аутобиографији.

претпостављене еквиваленције као природну, али и релативну, говорећи о Доситејевом дјелу, не морамо улазити у расправу о томе да ли је жанр образовног романа омеђен искључиво Гетеовим добом или се протеже до савремене књижевности, што нас лишава расправа које се обично покрећу и саме од себе када се потоња књижевност настоји тумачити помоћу ове жанровске одреднице. 
Ако пронађемо довољно разлога за, ако не апсолутно, бар релативно изједначавање аутобиографије и образовног романа како бисмо аутобиграфију посматрали као образовни роман, остаје да се образложи и зашто би се то у случају једног конкретног дјела уопште чинило и какве би користи од тога имала потенцијална интерпретација. Приступ Доситејевом дјелу Живот и прикљученија заснован на претпоставци да се као крајње литераризована аутобиографија, због тога, али и због начина на који представља образовни процес главног јунака (од дјетињства, младалачких заблуда, сукоба са тежњама породице, менторског дејства других људи, пута који није пука авантура, него кретање са тачно одређеним циљем, сазријевања и коначног измирења са свијетом кроз проналажења свога мјеста у општем поретку ствари) сасвим поклапа са жанровским одредницама образовног романа чини се разложним, јер прије свега омогућава актуализовање специфично литерарних, дакле, естетских аспеката дјела.

\section{3. ОБРАЗОВАњЕ (УЧЕНИКА КАО) ЧИТАЛАЦА - КАКО (У НА- СТАВИ) ИСКОРИСТИТИ ТУЂЕ НЕКРИТИЧКО ЧИТАЬЕ?}

Поред теоријских аргумената који дозвољавају да се уопште о Доситејевом дјелу говори као о образовном роману, важно је пронаћи и методичке - зашто бисмо се у наставном тумачењу ослањали на елементе образовног романа и у односу на њих заснивали методички приступ. Први аргумент би се могао односити на то да нам овакав приступ омогућава да актуализујемо све оне аспекте наведеног дјела који се тичу управо његових естетских (или литерарних) датости, као и улоге у грађењу једне нове културне парадигме, односно идеолошких датости. Наравно, до других треба доћи тек преко свестраног тумачења унутрашњих, естетских чинилаца текста.

Други аргумент, који происходи из првог, тицао би се онога што тумачење Доситејевог дјела као образовног романа може да да̂ савременој настави књижевности, и то поштујући све њене постулате. Ту се прије свега мисли на специфичан однос према читаоцу, што је једна од најважнијих одлика образовног романа. Наиме, неки аутори сматрају да су Гете и његови савременици (романтичари) покушали да изграде нови тип читаоца новим одважним наративним стратегијама које су захтијевале од читаоца да трага за значењем текста, обезбјеђујући тако образовну вриједност својим романима (видјети: Mahoney 1991: 101). Зато се у самом Гетеовом роману може препознати мноштво различитих стилова и наративних стратегија у служби 
формирања активног, осјетљивог и мудрог читаоца (Исто: 105). Ма колико да су имали у виду себи савремене, њемачке читаоце, ови аутори и изван оквира националне књижевности, али и изван оквира своје епохе, нарочитим квалитетом изабраних средстава, успијевају да комуницирају и са нама савременим читаоцима. Успијевају да и данашњег читаоца усмјере ка методама критичког мишљења, без обзира на то што је у међувремену дошло до губљења безусловног повјерења у моћи и домете разума. Доситеј има исти однос према читаоцу. Наставна интерпретација Живота и прикљученија могла би ово да узме као своје полазиште и исходиште - читав богати комуникацијски систем у Доситејевом дјелу могао би се подвести под окриље несумњиво постојане интенције образовања читаоца.

Образовање читаоца понајвише се одвија преко разобличавања сопственог погрешног, односно некритичког читања. Цјелокупан пут до зрелости - у формалном смислу композиција дјела, смишљен је тако да разобличи једну по једну претпоставку погрешног читања. То функционише као својеврсна телеологија дјела, јер око себе окупља све друге аспекте образовања. Стога би образовање читаоца, као и смисаона и формална телеологија текста, могло да постане један од кључних интеграционих чинилаца интерпретације, с обзиром на то да наставна „интерпретација обухвата књижевно дело у целини, али [да] се остварује преко избора његових доминантних вредности“ (Николић 2012: 218). Јасно је да се интерпретација не може засновати искључиво на једном интеграционом чиниоцу (о томе у: Исто: 219), што се и овдје има у виду. Елементи образовног романа, а нарочито они који за циљ имају образовање читаоца (ако свима то и није циљ), требало би да послуже као основа за избор оперативних, конкретнијих, интеграционих чинилаца ваљане интерпретације.

Тако би један од интеграционих чинилаца постала композиција која прати процес образовања главног јунака све до тренутка проналажења коначне сврхе живљења и дјеловања - писања, објављивања књига и подучавања свога народа. Пут до овог коначног циља сам по себи је изузетно занимљив, са много елемената авантуристичког, што ће свакако привући ученикову пажњу. При томе, иако је сваки од сегмената пута по себи занимљив и сврховит, дакле, композиционо врло ефектно уклопљен, приповједач не пропушта прилику да непосредно интензивира доживљај, као у сљедећем примјеру, када је стигао чак до Лондона као врхунца свога дугогодишњег путовања и када ће услиједити својеврстан повратак:

„Гди сам ја ово сада? Ко ли сам ја? Чињаше ми се као да сам се изнова у некакав нови свет родио. Необично представљаше ми се 
постигнути: јесам ли ја онај исти који је пре неколико дана с мојим комшијом Ником Путиним, из Баната, све покрај Бегеја у Срем, а одавде у црвени хајдучки опанци с Атанасијем покрај Дунава у Хорватску у великој итошти иђах? Сада на покрову таковог интова (у који за улести ваља се пењати по мердевинама) седим као неки римски диктатор, и победивши љуту скудост и суровог мучитеља убожество, аки у победоносном тријумфу улазим у славнији и лепши град него је икад Рим био, вмењајући себе тако благополучна зато што га видим и у њега улазим аки би сам мој био прекрасни Лондон.“ (Обрадовић 1997: 173)

Из овог примјера који долази на крајуㄹ, јасно се види да су сви композициони дијелови истом сврхом повезани (а један је од аргумената да су први и други дио јединствена, органска цјелина, без обзира на „накнадност“ другог дијела). Истовремено се очитује и да је композиција сасвим подређена образовном путу јунака, јер се управо уласком у Лондон, као најдаљу, односно најнедостижнију дестинацију, сасвим експлицитно говори о промјенама које су наступиле. Путовање као кретање кроз простор, односно наративно-композиционе блокове текста, истовремено је и кретање по унутрашњим просторима јунака ка просвијећености. Усхићење због констатоване промјене идентитета у облику реторског питања није лишено патоса, иако поређење са тријумфалним уласком у Рим које му слиједи има и хумористички призвук. Дакле, успостављена је изузетна паралела између наративно-композиционог организовања текста и образовног пута јунака који треба да постане узоран модел за сваког читаоца, што би у приступу овом дјелу требало уважити. На тај начин се показује да се у интерпретацији долази до вишеструке користи ако се ствари поставе тако да се „преко једног могу сагледати и многи други“ елементи дјела (Николић 2012: 219) - у овом случају образовни пут јунака преко композиције, или обрнуто, у зависности за који смјер се опредијелимо.

Образовање читаоца није само у домену моделоване композиције, односно образовног пута јунака, којим се рачуна на опонашање представљеног узорног случаја. У Доситејевом дјелу се користи читав арсенал средстава којим се дјелује на образовање читаоца. Једно од средстава су и бројни микрожанрови, попут дијалога, анегдота, афоризама, пословица

2 Могао се узети и примјер из неког другог сегмента путовања/образовања, који би једнако приказао постојећу паралелу. Овај с краја само свједочи о томе да је ријеч о постојаној телеологији. 
и других, који имају за циљ да разобличе погрешно читање и да, са друге стране, укажу на добробит читања са расуђивањем. У свим случајевима је интенција и више него очигледна. Са друге стране, прикривена је литерарним рјешењима и скоро неосјетно се остварује. Сви ови миркожанрови обилују елементима хумора. У том смислу можемо говорити о хумористичком образовном роману, са спорадичним сентименталним и пасажима са озбиљним, морализаторско-дидактичним тоном. Значај хумора у стварању пријатне и подстицајне атмосфере за доживљајно и истраживачко читање и свестрано тумачење је несумњив (о томе више у: Бајић 2011: 31 и даље). C обзиром на начина на који се хумористички елементи манифестују у Доситејевом дјелу, може се претпоставити да је ријеч о хотимичној, срачунатој стратегији образовања читаоца, која може да рачуна на успјех.

Приповједачево разобличавање властитог погрешног читања и некритичке примјене прочитаног у свакодневном животу благим и добронамјерним хумором, умјесто подсмијехом или иронијом, није одраз благонаклоности према себи, него прије према читаоцу. При томе, што је заблуда код младог Димитрија бивала озбиљнија, све су присутнији елементи хумора. Како је, упознавиши се са житијима светаца, млади читалац одлучио да слиједи њихов примјер, он дословно свој живот настоји да усклади са прочитаним. То по себи отвара могућност ка трагичном, једнако као и према комичном. Доситеј се опредијелио за друго рјешење и на видјело изнио комични несразмјер између уображених идеала и стварних услова живота. Поменута несразмјера се користи у свим погодним ситуацијама за продуковање хумора, као, на примјер, када се Димитрије саблажњава над помишљу да би га могли оженити:

„Но моја глава, пуна светиње, другојаче би мислила. Кога оженити? Мене? Сачувај боже! Боље сто пута да ме каква свирепа лавица или медведица с ноктима својим на парчета растргне, него да ме најлепша српска кћи у своје незлобиве, чисте девојачке наручи загрли!“ (Обрадовић 1997: 41)

Наративна стратегија којој је овдје писац прибјегао огледа се у двострукој перспективи - „светачкој“, незрелој, младалачкој и накнадној, зрелој, приповједачевој. Да нису сасвим стопљене, види се по незразмјери дисјунктивног односа ,лавица, медвједица-чисте дјевојачке наручи“. Стога је овај примјер парадигматичан за низ других у којима се циљ постиже на исти начин. 
Комуникација са читаоцем и придобијање његове пажње, али и наклоности, све зарад образовања, не одвија се само преко елемената хумора. Тако се присност са читаоцем гради и дијељењем, на примјер, интимних тренутака истинске радости и дивљења према љепотама Хопова и околине, које се завршава отвореним општењем са читаоцем: „Ево, мој љубезни читатељу, к каквим размишљенијам само воспоминаније хоповске красоте ум мој узвишује. О, место достојно да посвећено будеш мудрости и ученију и да се српским назовеш Парнасом!“‘ (Обрадовић 1997: 74) И други, сентименталнији пасажи, попут оних који доносе сјећања на сестру и мајку или посјету гробљу, имају исти циљ.

Наратер $^{3}$ са којим комуницира Доситеј аутор-приповједач требало би да буде оличење оног читаоца који ће се служити својим разумом, али и читаоца спремног за доживљавање, саосјећање, идентификацију. Методичким поступањем ученике зато треба усмјерити према оним текстуалним стратегијама које су срачунате за ову комуникацију. На тај начин би се остварила и интенција Доситејевог дјела и интенција савремене наставе књижевности, јер се огледају у развијању читаоца способног да ангажује све своје мисаоне и емоционалне капацитете при читању. ${ }^{4}$

Наставна интерпретација која би уважила све о чему је било ријечи, могла би се у потпуности остварити тек у средњој школи, и то понајвише у гимназијама, гдје се у цјелини чита први дио дјела ${ }^{5}$, што се овдје има у виду. Такав приступ би се могао прилагодити и ситуацијама када се програмом прописује један одломак, и на млађем и на старијем узрасту. Одговарајућим

3 Иако је наратер конструкција као и наратор, што дуго није било освијешћено у науци, па се правила разлика између аутора и наратора, али не и између читаоца и наратера (видјети: Prince 1980: 7), он овдје има ипак другачији (онтолошки) квалитет, паралелно са измјењеним карактером приповједача који у овом случају не може да се безусловно одвоји од аутора. Стога, комуникација са наратером не остаје само у оквиру текста, него прекорачује његове границе у одлучном иступању ка реалном читаоцу.

4 Драгана Вукићевић поводом Доситејевог концепта читања, који се испољава и у наведеним примјерима, запажа сљедеће: „Код Доситеја се контемплативни чин, промишљања прочитаног, спаја са опажајним доживљајем простора, простор око њега постаје слово, знак који треба прочитати. Он заиста шета и толкује свет и о томе пише - један знак преводи у други. Уобичајена метафора света као књиге и човека као њеног читаоца - јавља се у свом дословном значењу. [...] Књига је вид комуникације између аутора и читаоца, савршен у смислу брисања њихове временске или просторне удаљености.“(Вукићевић 2011: 215)

5 У случајевима гдје околности дозвољавају у видокруг би се могао довести и други дио, на примјер, кроз индивидуална задужења. На тај начин би се остварио свестранији увид у структуру, иначе јединственог дјела. Али, без обзира на то, приступ првом дијелу заснован на жанровским елементима образовног романа могао би бити довољан да се остваре врло комплексни образовни, васпитни и функционални циљеви. 
истраживачким задацима и испланираном динамиком интерпретације требало би ученике усмјеравати на оне сегменте Доситејевог дјела који су у служби комуникације са читаоцем и његовог образовања. На тај начин би корист по наставу била двостука. Са једне стране, биле би оставрене све важне претпоставке за ваљан интерпретативни приступ, а, са друге, и за развијање читалачких компетенција ученика на непосредан и ненаметљив начин.

Жанровски приступ књижевном дјелу у настави је специфичан по томе што подразумијева да „обрада узме у обзир и жанровску поставку текста, и његову аутономност, у мери како су оне остварене у сваком конкретном књижевном делу“ (Бајић 2007: 106). Када је ријеч о старијем узрасту, што се овдје највише и имало на уму, након свестране обраде која се заснива на уважавању жанровских елемената текста, било би пожељно направити искорак и ка уопштавању жанровских одредница. Дакле, пошто је ријеч о старијем узрасту, жанровски приступ и усвајање књижевнотеоријских појмова би се могао искористити као погодан начин за повезивање читалачког искустава ученика са научним мишљењем и теоријом жанрова (о овој могућности видјети: Бајић 2007: 115). Функционални аспекти теоријског савладавања елемената жанра у овом случају се, међутим, не испољавају само у виду оспособљавања ученика за разумијевање и примјену апстрактних појмова (савладаних индукцијом). Такво поступање тек треба да оствари своју потенцијалну функционалност. Наиме, жанровска матрица образовног романа протеже се кроз европску књижевност 19. и 20. вијека, постајући основа за умјетничку обраду код бројних класика. Свестрано разумијевање ових дјела, која су дио лектире у старијим разредима, није могуће без познавања карактеристика образовног романа. Поред тога, уопштавање жанровских одредница и озбиљније упуштање у историју жанра баца ново свјетло и на Доситејево дјело. Тиме се показује да је овај изузетан писац сасвим добро осјећао дух времена и да је стварао у складу са њим.

\section{4. ЗАКљУЧАК}

Доситејево дјело Живот и прикљученија својим литерарним богатством, књижевноисторијским и културним значајем представља својеврстан интерпретативни изазов. У наставним околностима изазовност је још снажнија. Она се огледа не само у приступу специфичностима дјела, него и у особеностима савремене читалачке публике из ученичке популације. Без обзира на потврђене вриједности Доситејевог дјела, однос савременог 
читаоца-ученика може бити проблематичан. Због тога је неопходно додатно посредно и непосредно припремати и мотивисати ученике за читање и тумачење овог дјела. Осим тога, неопходно је изнаћи пут којим ће се и сам процес читања и тумачења, када је унапријед остварена мотивација, успјешно одвијати. Предложени интерпретативни оквир има за циљ управо проналажење начина на које ће се остварити жива комуникација између Доситејевог дјела и ученика као читаоца и тумача.

Бројни су методички (и методолошки) путеви којима би се могло доћи до жељеног циља. Али, најбољим се чине они који прије свега настоје да уваже оне чиниоце успјешне комуникације које пројектује само дјело. Пошто Доситеј својом литерарном вјештином изнад свега настоји да образује читаоца, природно је дјелу приступити управо са те стране и све вријеме имајући то у виду, организовати наставну интерпретацију. Ипак, на крају и то ваља истаћи, колико је ова замисао заиста оперативна, треба да покаже тек практична разрада и примјена понуђеног интерпретативног оквира, уз уважавање свих оних стручних и методичких полазишта који такав приступ има као своју претпоставку.

\section{ЛИТЕРАТУРА}

Bajazetov-Vučen, A. (2000). „Vilhelm Majster, bezazleno posvojče života“. Reč 60/5: 507-538.

Бајић, Љ. (2007). „Улога жанра у настави књижевности“. Книжевност и језик 54, 1/2: 105-118. [Bajić, LJ. (2007). „Uloga žanra u nastavi književnosti“. Književnost i jezik 54, 1/2: 105-118.]

Бајић, Љ. (2011). „Доситеј Обрадовић и савремена педагогија“, у Доситеј u (српска) школа, ур. Д. Иванић (Београд: Задужбина Доситеја Обрадовића): 25-37. [Bajić, LJ. (2011). „Dositej Obradović i savremena pedagogija“, u Dositej i (srpska) škola, ur. D. Ivanić (Beograd: Zadužbina Dositeja Obradovića): 25-37.]

Вукићевић, Д. (2011). „Доситеј о читању“, у Доситеј и (српска) школа, ур. Д. Иванић (Београд: Задужбина Доситеја Обрадовића): 211-225. [Vukićević, D. (2011). „Dositej o čitanju“, u Dositej i (srpska) škola, ur. D. Ivanić (Beograd: Zadužbina Dositeja Obradovića): 211-225.]

Dobrijević, A. (2006). „Između obrazovanja i samoobrazovanja: od Bildunga do etike vrline“. Filozofija i društvo 1: 119-128.

Иванић, Д. (2008). „Доситеј Обрадовић и генеза српске прозе“, у Дело Доситеја Обрадовића 1807-2007, ур. Д. Иванић, В. Јелић (Београд: Задужбина Доситеја Обрадовића): 215-229. [Ivanić, D. (2008). „Dositej 
Obradović i geneza srpske proze“, u Delo Dositeja Obradovića 18072007, ur. D. Ivanić, V. Jelić (Beograd: Zadužbina Dositeja Obradovića): 215-229.]

Jakobs, J., Krauze, M. (2000). „Nemački obrazovni roman. Istorija žanra od XVII do XX veka“. Reč 60/5: 379-398.

Кречмер, А. (2008). „Доситејев језик и школски приручници његовог времена“, у Дело Доситеја Обрадовића 1807-2007, ур. Д. Иванић, В. Јелић (Београд: Задужбина Доситеја Обрадовића): 73-85. [Krečmer, A. (2008). „Dositejev jezik i školski priručnici njegovog vremena“, u Delo Dositeja Obradovića 1807-2007, ur. D. Ivanić, V. Jelić (Beograd: Zadužbina Dositeja Obradovića): 73-85.]

Ломпар, М. (2000). „Дух просвећености у српској аутобиографији“, у Живот и дело Доситеја Обрадовића, ур. П. Пијановић (Београд: Завод за уџбенике и наставна средства): 429-435. [Lompar, M. (2000). „Duh prosvećenosti u srpskoj autobiografiji“, u Život $i$ delo Dositeja Obradovića, ur. P. Pijanović (Beograd: Zavod za udžbenike i nastavna sredstva): 429-435.]

Марковић, С. Ж. (2008). „Живот и прикљученија Димитрија Обрадовича, нареченог у калуђерству Доситеја њим истим списат и издат - npemходница или почетак српске књижевности за деиу“, у Дело Доситеја Обрадовића 1807-2007, ур. Д. Иванић, В. Јелић (Београд: Задужбина Доситеја Обрадовића): 15-23. [Marković, S. Ž. (2008). „Život i priključenija Dimitrija Obradoviča, narečenog u kaluđerstvu Dositeja njim istim spisat i izdat - prethodnica ili početak srpske književnosti za decu“, u Delo Dositeja Obradovića 1807-2007, ur. D. Ivanić, V. Jelić (Beograd: Zadužbina Dositeja Obradovića): 15-23.]

Mahoney, D. F. (1991). "The Apprenticeship of the Reader: The Bildungsroman of the 'Age of Goethe" ", in Reflectin and Action: Essays on the Bildungsroman, ed. J. Hardin (Columbia: University of Soth Carolina Press): 97-118.

Милинчевић, В. (2008). „Афоризам у Доситејевом делу“, у Дело Доситеја Обрадовића 1807-2007, ур. Д. Иванић, В. Јелић (Београд: Задужбина Доситеја Обрадовића): 23-33. [Milinčević, V. (2008). „Aforizam u Dositejevom delu“, u Delo Dositeja Obradovića 1807-2007, ur. D. Ivanić, V. Jelić (Beograd: Zadužbina Dositeja Obradovića): 23-33.]

Moreti, F. (2000). „Bildungsroman kao simbolička forma“. Reč 60/5: 417-452. Николић, М. (2012). Методика наставе српског језика и књижевности. Београд: Завод за уџбенике. [Nikolić, М. (2012). Metodika nastave srpskog jezika i književnosti. Beograd: Zavod za udžbenike.] 
Обрадовић, Д. (1997). Живот и прикљученија. Београд: Завод за уџбенике и наставна средства. [Obradović, D. (1997). Život i priključenija. Beograd: Zavod za udžbenike i nastavna sredstva.]

Prince, G. (1980). „Introduction to the Study of the Narratee“. in Readerresponse criticism: From formalism to post-structuralism. ed. J. P.Tompkins (Baltimore: JHU Press): 7-26.

Стојнић, М. (1990). „Прилог проучавању жанра Доситеја Д. Обрадовића 'Живот и прикљученија'“, Доситеј Обрадовић - Човек и дело међу народима. Научни састанак слависта у Вукове дане 19/2, 173-178. [Stojnić, M. (1990). „Prilog proučavanju žanra Dositeja D. Obradovića 'Život i priključenija'“, Dositej Obradović - Čovek i delo među narodima. Naučni sastanak slavista u Vukove dane 19/2, 173-178.] 
Jelena Todorović

University of Belgrade

Faculty of Philology - doctoral studies, module Serbian Literature

Belgrade

jelena_4@yahoo.com

\section{GENRE-BASED ELEMENTS OF THE EDUCATIONAL NOVEL AS A POSSIBLE INTERPRETATIVE BASE IN INTERPRETING ŽIVOT I PRIKLJUČENIJA BY DOSITEJ OBRADOVIĆ (METHODOLOGICAL PERSPECTIVE)}

\section{Summary}

The paper deals with a different way of interpreting Život $i$ priključenija by Dositej Obradović by using elements of the educational novel. The first part of the paper is devoted to theoretical issues of that assumption - how to observe an autobiography as something based on generic determinants of another genre; what are the requirements of such practice and what are the benefits for the interpretation. Methodological perspective is introduced in the second part of the paper. It discusses the principal issues of genrebased approach in the classroom, but the emphasis is on the structure of the educational novel that permeates this paper. Dositej's work puts an emphasis on educating the reader to recognize the narrator's own misreadings. Also, the narrator's own unmasking of false readings and uncritical application of reading turns into everyday gentle and benevolent humor, rather than derision or irony. It is not a reflection of benevolence towards themselves, but rather towards the reader. Unmasking of narrator's reading misconceptions is the path to enlightenment. In fact, the most important aspects of this structure are used with the purpose of educating the readers. The conclusion is that this structure may represent a central point and a central integration factor for the interpretation of this work in teaching. On the other hand, it might be useful practice for students in the area of critical reading.

Key words: educational novel, autobiography, reader, genre, teaching interpretation

Primljeno: 27. 3. 2016.

Prihvaćeno: 1. 5. 2016. 